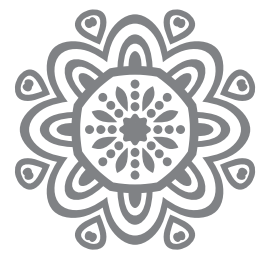

\title{
RELEVANSI TASAWUF DI ERA MODERN
}

\author{
Sirajuddin Zar \\ Guru Besar UIN Imam Bonjol Padang
}

\begin{abstract}
Islam is not just a legalistic-formalistic side, but it also has an esoteric dimension. Sufism is an important element in Islam which is more focused on the esoteric aspects of Islam. This inward aspect of Islam is more influenced by feelings (zauq) and is personal and in revealing its teachings often uses figurative words (matsal) and symbols (ramz). The aim of the Sufi is to get as close as possible to God, so that he can see God with the eyes of the heart, even his spirit can be united with the spirit of God. Islamic mysticism does not deny science, even Islamic mysticism contributes a lot of ideas in the fields of philosophy, literature, music, dance, psychology, and modern science. The problem of alienation is a psychological problem. Humans play a role as the cause of the emergence of alienation and at the same time as a victim who must bear the consequences. In the context of Islamic teachings, to overcome the alienation of the human soul and free from the pain of alienation, it must instead make God the ultimate goal, the Supreme Being and the Absolute. All relative and relative existence is meaningless before the existence of the absolute.
\end{abstract}

Key Word: Islam, Tasawuf, Sains.

\section{A. Pendahuluan}

Tasawuf merupakan unsur yang penting dalam Islam. Jika unsur ini dihilangkan, berarti agama bagaikan badan tanpa nyawa. Karenanya hal ini perlu disosialisasikan, Islam bukan hanya sisi legalistik-formalistik saja, tetapi ia juga memiliki dimensi esoterik. Kemajuan-kemajuan Barat pada era modern yang telah berhasil mengembangkan kecerdasan intelektualnya di berbagai bidang kehidupan, termasuk dalam bidang sains dan teknologi yang kemajuannya tidak dapat dibendung, namun memiliki kekeringan dari aspek kerohanian dan akan menimbulkan malapetaka dalam berbagai bidang. Hal tersebut terjadi karena 
jiwa mereka dalam kekosongan dari nilai-nilai spiritual, disebabkan tidak punya oreintasi yang jelas dalam menapaki kehidupan di alam dunia ini. Sayyid Hussein Nasr Menilai bahwa keterasingan (alienasi) yang di alami oleh orang-orang Barat karena peradaban modern yang mereka bangun bermula dari penolakan (negation) terhadap hakikat ruhaniyah secara gradual dalam kehidupan manusia. Akibatnya, manusia lupa terhadap eksistensi dirinya sebagai 'abid (hamba) di hadapan Tuhan karena telah terputus dari akar-akar spiritualitas. Hal ini merupakan fenomena betapa manusia modern memiliki spiritualitas yang akut. Pada gilirannya, mereka cenderung tidak mampu menjawab berbagai persoalan hidupnya dan kemudian terperangkap dalam kehampaan dan ketidakbermaknaan hidup.

Untuk menangkal hal dimaksud perlu dihidupkan pendidikan spiritual. Bagi kaum sufi ajaran spiritual ini merupakan cara utama untuk mengendalikan hawa nafsu. Bila ajaran tasawuf tentang kesucian jiwa dan akhlak mulianya sudah terlaksana dengan baik, maka manusia akan menjadi hamba Allah yang membawa kedamaian di alam semesta ini. Keimanan atau kepercayaan pada agama (Tuhan) itu, secara pragmatis merupakan kebutuhan untuk menenangkan jiwa, terlepas apakah objek kualitas iman itu benar atau salah. Secara psikologis, ini menunjukkan bahwa agama selalu mengajarkan dan menyadarkan akan nasib keterasingan manusia dari Tuhannya. Manusia, bagaimanapun juga tidak akan dapat melepaskan diri dari agama, karena manusia selalu punya ketergantungan kepada kekuatan yang lebih tinggi diluar dirinya (Tuhan) atau apapun bentuknya dan agama diturunkan oleh Allah untuk memenuhi kebutuhan dasar manusia sebagai makhluk rasional dan spiritul.

Pandangan dunia sekuler, yang hanya mementingkan kehidupan duniawi, telah secara signifikan menyingkirkan manusia modern dari segala asfek spiritual. Akibatnya, mereka hidup secara terisolir dari dunia-dunia lain yang bersifat nonfisik, yang diyakini adanya oleh para Sufi. Mereka menolak segala dunia nonfisik seperti dunia imajinal atau spiritual sehingga terputus hubungan dengan segala realitas-realitas yang lebih tinggi daripada sekedar entitas-entitas fisik. Manusia sebenarnya menurut fitrahnya, tidak dapat melepaskan diri dari kehidupan spiritual, karena memang diri manusia terdiri dari dua unsur yaitu jasmani dan ruhani. Dalam diri manusia, tuntutan kebutuhan jasmani dan ruhani harus dipenuhi secara bersamaan dan seimbang, kebutuhan jasmani dapat terpenuhi dengan hal-hal yang bersifat materi sedangkan kebutuhan ruhani harus dipenuhi dengan yang bersifat spiritual seperti ibadah, dzikir, etika dan amal shaleh lainnya. Apabila kedua hal tersebut tidak dapat dipenuhi secara adil maka kehidupan manusia itu dapat dipastikan akan mengalami kekeringan dan kehampaan bahkan tidak menutup kemungkinan bisa mengalami setres. 
Salah satu kritik yang ditujukan kepada ilmu pengetahuan dan teknologi moderen dari sudut pandang Islam ialah karena ilmu pengetahuan dan teknologi modern bertumpu pada prestasi sains dan teknologi dan meminggirkan dimensi transendental Ilahiyah. Akibatnya, kehidupan masyarakat modern menjadi kehilangan salah satu aspeknya yang paling fundamental, yaitu asfek spiritual.

\section{B. Esensi Tasawuf}

Prinsip asasi tasawuf, yang dalam literatur Barat disebut sufisme, ${ }^{1}$ adalah bahwa tidak ada wujud hakiki kecuali Allah. Dengan demikian, kalimat syahadat pertama, Asyhadu 'an lâ ilaha illa Allah (Aku bersaksi bahwa tidak ada Tuhan selain Allah), berarti lâ maujûda illa Allah (tidak ada wujud kecuali wujud Allah). Sedangkan roh manusia, menurut tasawuf, anugerah Tuhan dan berasal dari roh-Nya. Karena itu, ia ingin berhubungan dengan sumber aslinya. Perhubungan itu dapat mengambil bentuk al-mahabbah, al-márifah,al-hulûl (al-nâsût Allah menunggal dengan al-lâhût manusia) dan al-ittihâd (roh manusia manunggal dengan roh Allah). ${ }^{2}$ Pendapat roh manusia berasal dari roh-Nya memang sejalan dengan ayat-ayat al-Qur'an. Di antara ayat itu adalah : (artinya)

Maka apabila Aku (Allah) telah menyempurnakan kejadiannya (manusia), dan telah meniupkan ke dalamnya roh-Ku, maka tunduklah kamu kepadanya dengan bersujud (Q.S Al-Hijr/15:29 dan Shad/38:72). ${ }^{3}$

Rûhîy dalam ayat ini, bagi kaum sufi, bukanlah berarti roh (ciptaan)-Ku atau roh ciptaan Allah, sebagai lazim atau biasa diartikan, tetapi ia adalah betul-betul roh-Ku atau roh Allah.

Tasawuf atau sufisme adalah kegiatan yang lebih dititikberatkan pada aspek esoterik Islam. Ia berbeda sama sekali dengan orientasi fiqh dan syariah yang lebih mengarah kepada eksoterisme dalam Islam. Kegiatan aspek ke dalam dari Islam ini lebih banyak dipengaruhi oleh perasaan (zauq) dan bersifat personal bahkan dalam pengungkapkan ajarannya sering menggunakan kata kiasan (matsal) dan lambang (ramz). Untuk memahami ajaran tasawuf ini harus dengan semangat metaforis atau tafsir batini. Kendatipun mereka memakai metode seperti ini, namun mereka tetap berpegang pada wahyu. Sedangkan aspek keluaran dari Islam lebih banyak dipengaruhi oleh rasio, atau setidak-tidaknya oleh rasio dan wahyu yang berbentuk syariah.

\footnotetext{
1973), hal. 3.

${ }^{1}$ Titus Burchard's, An Intruduction to Sufi Doctrine, (Lahore: SH Muhammad Ashraf, Cet I, hal. 50.

${ }^{2}$ Harun Nasution, Falsafat dan Misticisme dalam Islam, (Jakarta: Bulan Bintang, 1973),

${ }^{3}$ Titus Burchard's, An Intruduction to Sufi Doctrine, hal. 3
} 
Tujuan sufi adalah mendekatkan diri sedekat mungkin dengan Allah, sehingga ia dapat melihat Allah dengan mata hati bahkan rohnya dapat manunggal dengan roh Allah. Filsafat yang menjadi dasar tentang ini, adalah :

a. Allah bersifat rohani, maka yang dapat mendekatkan diri dengan-Nya adalah roh manusia bukan jasadnya.

b. Allah adalah Maha Suci, maka yang dapat diterima Allah untuk mendekat kepada-Nya adalah roh yang suci. ${ }^{4}$

Dalam ajaran tasawuf, seorang sufi dalam mendekatkan diri kepada Allah, bahkan sedekat mungkin, bukanlah dengan mudah begitu saja, akan tetapi ia harus menempuh jalan tertentu yang sulit dan panjang, dengan istilah penuh onak dan duri. Jalan ini disebut dengan maqâmât (jamak dari maqâm) atau station. Maqâmât adalah disiplin kerohanian yang ditunjukkan seseorang sufi berupa pengalaman-pengalaman yang dirasakan dan diperoleh melalui usaha-usaha tertentu. Usaha sufi seperti ini terus menerus tanpa henti.

Dalam ajaran tasawuf, di samping istilah maqâm atau stasiun, terdapat pula istilah ahwâl (jamak dari hâl). Ia merupakan keadaan mental yang datang dengan sendirinya ketika sufi menempuh maqâm tertentu. Dengan kata lain, ia merupakan anugerah Allah kepada sufi, tanpa diusahakan olehnya. ${ }^{5}$ Selain itu berbeda dengan maqâm, hâl bersifat temporer; suatu saat ia datang tetapi di saat lain ia pergi. Istilah yang populer tentang ini ialah maqâm mukâsib wa hâl muwâhib (maqâm permanen atau diusahakan dan hâl temporal atau anugerah).

Dengan demikian setiap sufi harus berusaha untuk mencapai maqâm tertentu, sehingga ia merasa telah terbuka hubungannya dengan Allah dan berada di hariban-Nya. Sebagai indikator bahwa ia telah berada dekat dengan Tuhan, adalah ia menerima anugerah dan rahmat dari Allah dalam bentuk sikap mental tertentu (hâl). Dengan sikap mental pemberian Allah inilah ia telah mendapatkan suatu keyakinan bahwa ia benar-benar telah menjadikan Allah sebagai tumpuan harapannya.

Adapun jumlah maqâmât yang ditempuh oleh para sufi ternyata berbeda-beda, tergantung pada pengalaman pribadi sufi yang bersangkutan. Jadi seorang sufi berbeda jumlah maqâmât-nya dengan sufi yang lain. Karena itu, wajar dalam berbagai buku tasawuf ditemukan aneka ragam maqâmât tersebut. Sebagai contoh Abu Nasr al-Sarraj menyebut tujuh maqâmât, yakni taubat, wara', zuhud, faqr, shabr, tawakkal dan ridha. ${ }^{6}$ Sedangkan Abu Bakr Muhammad

\footnotetext{
${ }^{4}$ Ibn al-Asir, al-Kâmil fi al-Târîkh, (Beirut: Dâr al-Fikr, 1966), hal. 129.

${ }^{5}$ Ibn al-Asir, al-Kâmil fi al-Târîkh, hal. 129.

${ }^{6}$ Harun Nasution, Falsafat dan Misticisme dalam Islam, hal. 62.
} 
Al-Kalabazi mengemukakan maqâmât yang lebih banyak yakni taubat, zuhud, faqr, tawadhu', taqwa, tawakkal, ridha, mahabbah dan ma'rifah. ${ }^{7}$ Kendatipin jumlah maqâm masing-masing sufi berbeda, tetapi pada maqâm pertama mereka sama atau sepakat, yakni taubat.

Pengalaman-pengalaman kerohanian para sufi dimaksud dapat diketahui dari ucapan-ucapan mereka. Namun, di antara ucapan-ucapan itu, yang diistilahkan syathahât (mabuk kepayang) kadang-kadang ganjil kedengarannya. Kaum sufi, dengan banyak beribadah, taubat dan berzikir, merasa mendapat kebahagiaan. Di antara mereka terdorong oleh maksud baik untuk berbagi kebahagiaan, mereka berusaha menjelaskan pengalaman kesufian yang mereka rasakan kepada orang lain. Padahal pengalaman seperti itu tidak terwadahi oleh kata-kata dan tidak terpahami oleh masyarakat biasa. Akibatnya, terjadilah kesalahpahaman yang meresahkan bahkan mereka dinilai telah menyimpang dari agama Islam.

Perlu pula dijelaskan bahwa tentang persoalan asal usul tasawuf terdapat beberapa teori. Pada dasarnya teori-teori itu dapat dikelompokkan menjadi dua. Pertama, teori yang menyatakan bahwa tasawuf itu berasal dari agama lain, seperti Kristen, Hindu dan Budha. Bahkan ada juga yang menghubungkan dengan teori Plotinus dan filsafat mistik Pythagoras. Kedua, teori yang mengatakan tasawuf berakar dan tumbuh dari ajaran Islam itu sendiri. ${ }^{8}$

Teori pertama yang menganggap tasawuf sebagai paham yang dimasukkan dari luar, tentu saja bukan tanpa alasan. Memang paham-paham yang terdapat pada agama-agama dan filsafat tersebut terkesan sama dengan paham yang terdapat dalam tasawuf. Namun, sebenarnya tidaklah dapat disamakan, melainkan kebetulan identik saja. Sebenarnya ajaran tasawuf masih dalam kerangka ajaran Islam, karena al-Qur'an dan hadis dapat dijadikan sebagai dasar pengembangan ajaran tasawuf. Di antara ayat-ayat dimaksud ialah surat al-Baqarah/2:186, yang artinya: Dan apabila hamba-hamba-Ku bertanya kepadamu (Muhammad) tentang Aku, maka sesungguhnya Aku dekat. Aku kabulkan permohonan orang yang berdo'a apabila ia berdo'a kepada-Ku. Hendaklah mereka itu memenuhi (perintah)-Ku dan beriman kepada-Ku. Agar mereka memperoleh kebenaran. Surat al-Baqarah/2:115, yang artinya: Dan milik Allah timur dan barat. Kemanapun kamu menghadap di sanalah wajah Allah. Sungguh Allah Mahaluas lagi Maha Mengetahui. Surat Qâf/50:16, yang artinya: ..., dan Kami lebih dekat kepadanya daripada urat lehernya. Surat al-Anfâl/8:17, yang artinya: Maka (sebenarnya) bukan kamu yang membunuh mereka, melainkan Allah

\footnotetext{
${ }^{7}$ Al-Kalabazi, al-Ta'arruf li Mazhab ahl al-Tashawwuf, (Kairo: al-Maktabat al-Kulliyat al-Azhariyat, 1969). hal. 111-112.

${ }^{8}$ Harun Nasution, Falsafat dan Misticisme dalam Islam, hal. 52-53.
} 
yang membunuh mereka, dan bukan engkau yang melempar ketika engkau melempar, tetapi Allah yang melempar. (Hal demikian) untuk memberi kemenangan kepada orang-orang mukmin, dengan kemenangan yang baik. Sungguh Allah Maha Mendengar lagi Maha Mengetahui. Di antara hadis tersebut, seperti hadis: man 'arafa nafsahu fa qad 'arafa rabbahu (Orang yang mengetahui dirinya, itulah orang yang mengetahui Tuhannya).

Dengan demikian dapat ditegaskan, bahwa andaikan paham mistisisme luar Islam itu tidak muncul, maka dalam Islam akan muncul sendiri ajaran tasawuf. Akan tetapi, perlu dipahami bahwa ajaran tasawuf yang dikembangkan oleh para sufi adalah sebagai suatu penafsiran mereka tentang al-Qur'an dan hadis dan bersifat ijtihad yang termasuk ke dalam kelompok ajaran al-mutasyâbihât. Dengan kata lain, ijtihad para sufi ini berpeluang untuk salah dan benar sebagaimana halnya hasil ijtihad dalam disiplin ilmu-ilmu Islam lainnya.

\section{Tasawuf Era Klasik dan Pertengahan}

Sejarah menuturkan bahwa era klasik Islam dapat disebut era perkembangan peradaban Islam dalam bidang sains dan agama termasuk dalam bidang tasawuf. Pada era ini lahirlah sufi-sufi besar kenamaan seperti Rabiah al-Adawiah (713-801) dengan al-mahabbah-nya, Zunnun al-Misrih dan al-Ghazali dengan al-márifah-nya, Abu Yazid al-Bustami (w.874 M) dengan al-fanâ, al-baqầ dan al-ittihâd-nya, Husain ibn Mansur al-Hallaj (858-922 M) dengan al-hulûl-nya, Muhy al-Din ibn al-Arabi (1165-1240 M) dengan wahdat al-wujûd-nya, dan lainnya..

Berbeda dengan era klasik, era pertengahan pemikiran Islam dalam bidang sains dan agama termasuk sufisme tidak berkembang, sehingga pada era pertengahan ini Islam tidak lagi menghasilkan ulama-ulama besar sufi seperti era klasik. Karena itu, yang perlu mendapat jawaban segera, kenapa tasawuf dapat berkembang pada era klasik dan mandeg pada era pertengahan. Untuk menjawab hal ini perlu dilihat metode berpikir umat pada kedua era itu.

Dalam sejarah pemikiran Islam dikenal dua metode berpikir, yakni metode berpikir rasional dan metode berpikir tradisional. Di era klasik ulama-ulama Islam menganut metode berpikir rasional dengan ciri-cirinya sebagai berikut:

1. Akal mempunyai kedudukan yang tinggi.

2. Pemakaian takwil, dengan kata lain, akal mengambil arti metaforis dari ayat.

3. Kebebasan berpikir yang hanya dibatasi oleh ayat-ayat al-muhkamât dan ajaran Islam yang bersifat absolut. 
4. Adanya sunnatullah atau kausalitas di alam.

5. Sikap dinamis. ${ }^{9}$

Dengan metode berpikir rasional ini, berarti ulama-ulama era klasik mengembangkan pemikiran yang luas, pemikiran mereka hanya diikat oleh dogma-dogma yang sedikit, karena itu tasawuf (juga sains dan ilmu agama lainnya) dapat berkembang dengan baik.

Perlu dipahami, sekalipun metode ini memberikan kedudukan yang tinggi pada akal, namun ia tidak pernah menepiskan atau membelakangi wahyu. Wahyu tetap diperlukan dan akal tidak bisa menyalahi wahyu. Akan tetapi, apabila akal bertentangan dengan teks wahyu, maka yang diambil adalah arti metaforisnya, sehingga pendapat akal dan arti ayat menjadi sejalan. Dengan kata lain, yang dilanggar di sini bukan ayat tetapi arti tekstual ayat. Demikian juga arti metafora yang diambil tidak boleh bertentangan dengan prinsip wahyu (alQur'an).

Dengan demikian sekalipun dalam era klasik ini perkembangan tasawuf cukup luas, namun ia tidak pernah melanggar wahyu. Memang sufi dalam ucapan-ucapannya ketika al-ittihâd dan al-hulûl umpamanya, terkesan sebagai Allah. Akan tetapi tidaklah demikian, yang sebenarnya ialah Allah berbicara melalui lidah sufi yang bersangkutan. Yang mengaku sebagai Allah bukanlah sufi, melainkan Allah sendiri, sedangkan roh sufi telah bersatu (menunggal) dengan roh-Nya. Kiranya itulah sebabnya al-Ghazali yang terkenal serangan pedasnya terhadap para filosof tidak mengkafirkan Abu Yazid dan al-Hallaj, yang ia katakan berbicara dalam keadaan "tidak sadarkan diri," padahal pendapat mereka lebih 'hebat' daripada pendapat para filosof. ${ }^{10}$

Perlu ditegaskan bahwa kaum sufi era klasik orientasi mereka tidaklah keakhiratan semata, akan tetapi mereka juga melakukan kewajiban-kewajiban sosial kemasyarakatan. Tugas sufi adalah mengajak orang ke jalan yang benar, ada di antara mereka yang aktif berdakwah, bahkan mereka turut aktif dalam peperangan. ${ }^{11}$ Karena menurut mereka, meninggalkan kewajiban dalam bidang sosial kemasyarakatan termasuk perbuatan dosa. Orang yang berdosa, menurut mereka, tidak mungkin mendekati Allah dan Allah tidak akan menerima orangorang yang berdosa. 1997, hal. 9

${ }^{9}$ Sirajuddin Zar, Logika Berpikir Dalam Islam, Makalah, Seminar IKIP Padang, 31 Juli

${ }^{10}$ Harun Nasution, Kedudukan Tasawuf Dalam Islam, Kumpulan Makalah Paramadina, Jakarta, tt, hal. 12.

${ }^{11}$ Reynold A Nicholson, The Mistics of Islam, (London: Routledge and Kegan Paul, 1975), hal. 52 . 
Akan tetapi amat disayangkan bahwa umat Islam setelah era klasik Islam yang sukses dalam mengembangkan tasawuf (juga sains dan ilmu agama pada umumnya) meninggalkan metode berpikir rasional dan menggantinya dengan metode berpikir tradisional. Ciri-ciri metode berpikir tradisional :

1. Akal mempunyai kedudukan yang rendah.

2. Akal tunduk kepada arti tekstual dari ayat.

3. Kehendak mutlak Tuhan.

4. Tidak ada sunnatullah atau kausalitas yang tak berubah di alam.

5. Sikap pasif. ${ }^{12}$

Dengan demikian ulama-ulama Islam era pertengahan mengembangkan metode berpikir tradisional. Metode berpikir seperti ini akan membawa umat Islam berpikir sempit, dengan kata lain, banyak dogma yang membatasinya. Metode berpikir tradisional memberikan kedudukan yang rendah pada akal, karena itu tasawuf sulit berkembang, sebab kaum sufi lebih cenderung mengambil arti metaforis ayat. Sedangkan di sini akal tunduk kepada arti tekstual dan akal tidak mampu mengambil arti majazi dari ayat.

Pada pihal lain, era pertengahan ini kebebasan pemikiran ulama telah banyak yang mengikatnya, tidak hanya ajaran-ajaran dasar tetapi juga hasil ijtihad para sahabat dan para ulama besar. Bahkan ada anggapan bahwa pintu ijtihad telah tertutup. Karenanya, banyak ulama pada era ini bersikap taklid kepada ulama sebelumnya.

Demikian juga tasawuf sulit berkembang apabila bertolak pada kekuasaan dan kehendak mutlak Allah tanpa aturan. Penekanan pada pemikiran seperti ini akan melahirkan paham dan perasaan dikalangan umat Islam bahwa Allah Maha Kuasa dan Maha Agung. Allah dalam keadaan begini adalah Allah yang ditakuti dan tidak mungkin didekati. Paham ini bertentangan dengan kaum sufi yang memandang bahwa Allah Maha Pengasih lagi Maha Penyayang dan dekat sekali dengan manusia. Allah bukan ditakuti, tetapi disayangi.

Patut juga dijelaskan pada era pertengahan (1250-1800 M) perkembangan tasawuf mengambil bentuk tarekat. Ia merupakan organisasi tasawuf yang dibentuk oleh murid-murid sufi besar untuk melestarikan ajaran-ajaran gurunya. Akan tetapi terkadang ia telah menyimpang dari ajaran-ajaran gurunya. Hal ini lumrah terjadi, sesuai dengan sunatullah, pemahaman seseorang terhadap pendapat sebelumnya cenderung berubah bahkan tidak mustahil menyimpang 1997, hal. 9

${ }^{12}$ Sirajuddin Zar, Logika Berpikir Dalam Islam, Makalah, Seminar IKIP Padang, 31 Juli 
dari pendapat aslinya. Karena itu, menurut Harun Nasution, ada di antara ajaran tarekat telah menyimpang dari ajaran sufi sebelumnya, yakni mensucikan diri dan berada dekat dengan Allah. Bahkan tarekat ada pula yang telah menyalahi ajaran dasar sufi dan syari’at Islam, sehingga timbullah pertentangan-pertentangan antara kaum syariat dan tarekat. Selain itu, ada pula di antara ajaran tarekat yang menekankan kehidupan rohani saja dan mengabaikan kehidupan duniawi, bahkan ajaran tawakal sufi ialah mengabaikan usaha. Dengan kata lain, ajaran yang dikembangkan tarekat ialah orientasi akhirat semata dan sikap tawakal. ${ }^{13}$

Dengan demikian, dalam era pertengahan ini yang berkembang bukan tasawuf tetapi adalah tarekat-tarekat. Ia sangat besar pengaruhnya dalam masyarakat Islam. Hal ini terkesan sebagai sebuah iklan, --agar berpengaruh dalam masyarakat-- untuk mendorong orang masuk tarekat. Justru itulah diagnosa tokoh-tokoh pembaharu dalam Islam, seperti Jamaluddin al-Afghani, Muhammad Abduh dan Rasyid Ridha ada benarnya bahwa tarekat sebagai salah satu faktor yang membawa pada kemunduran umat Islam. ${ }^{14}$

\section{Tasawuf dan Urgensinya di Era Global}

Telah disinggung bahwa era global ditandai dengan kepesatan kemajuan ilmu pengetahuan dan teknologi di segala bidang. Sebagai contoh dengan teknologi komunikasi yang canggih, arus informasi akan mengalir dengan derasnya melintasi batas negara tanpa dapat dihambat oleh kekuatan fisik. Perubahan demi perubahan berjalan sangat cepat, bahkan sulit terikuti.

Sejarah menuturkan bahwa IPTEK di Barat lahir dan dibersarkan oleh pertarungan sengit antara saintis melawan gereja yang bengis terhadap dirinya. Pertarungan ini dilanjutkan dengan kekejaman agamawan (baca: gerejawan) terhadap saintis, yang dikenal dengan istilah inquisisi. Contoh yang terbaik dalam hal ini dapat dilihat pada praktek pemimpin Ordo Benedictine yang diangkat ke layar perak melalui film The Name of the Rose.

Kemajuan IPTEK dalam era global ini telah sampai kepada apa yang disebut dengan the post industrial society, yaitu masyarakat secara material telah sampai pada taraf makmur. Peralatan-peralatan hidup telah terkendali secara mekanik dan otomatis. ${ }^{15}$ Sepertinya hidup bertambah mudah, enak dan nyaman. Akan tetapi ternyata kenyamanan material tidak selamanya membawa kepada kebahagiaan rohani. Sebenarnya aspek kerohanian inilah sebagai harkat

\footnotetext{
${ }^{13}$ Harun Nasution, Kedudukan Tasawuf Dalam Islam, hal. 28.

${ }^{14}$ Harun Nasution, Kedudukan Tasawuf Dalam Islam, hal. 28-29

${ }^{15}$ Sayyed Hossein Nasr, Man and Nature: The Spritual of Crisis Man, (London: A Mandala Book-George Allen \& Unwin Ltd, 1976), hal. 21-22.
} 
kemanusiaan. Bila hal ini terabaikan akan membawa kekurangan yang paling serius yang menyangkut sisi manusia yang terpenting dan yang paling dalam.

Tasawuf merupakan unsur yang penting dalam Islam. Jika unsur ini dihilangkan, berarti agama bagaikan badan tanpa nyawa. Karenanya hal ini perlu disosialisasikan, Islam bukan hanya sisi legalistik-formalistik saja, tetapi ia juga memiliki dimensi esoterik. Telah dituturkan sebelumnya bahwa kaum sufi bukanlah orientasi keakhiratan semata. Mereka juga tidak mengabaikan tugas-tugas sosial kemasyarakatan. Kehidupan dunia, sebagai sarana bukan tujuan, mereka gunakan seperlunya.

Menyimak dari kemajuan-kemajuan Barat pada era global ini yang kering dari aspek kerohanian, akan menimbulkan malapetaka dalam berbagai bidang. Untuk menangkal hal dimaksud perlu dihidupkan pendidikan spiritual. Bagi kaum sufi ajaran spiritual ini merupakan cara utama untuk mengendalikan hawa nafsu. Bila ajaran tasawuf tentang kesucian jiwa dan akhlak mulianya sudah terlaksana dengan baik, maka manusia akan menjadi hamba Allah yang membawa kedamaian di alam semesta ini.

Berdasarkan kenyataan-kenyataan di atas dapat ditegaskan bahwa pada era global ini perlu dihidupkan kembali ajaran-ajaran tasawuf dengan bentuk baru atau neo sufisme yang sesuai dengan kondisi dan situasi. Penekanan tasawuf tidak lagi untuk mencapai al-ittihâd dengan Allah, akan tetapi lebih menekankan kepada transedental Allah, dan tasawuf dipandang sebagai jalan untuk mencapai kesempurnaan akhlak dan kebersihan jiwa. Akhlak yang hendak diwujudkan ialah "tiruan" dari akhlak Allah. Hal ini sesuai dengan hadis Nabi Muhammad SAW. : Takhallaqû bi akhlâq Allah (Hiasi dirimu dengan akhlak Allah). Kemudian sifat eskapisme dan anti keduniaan segera diganti dengan mengembangkan sikap positif terhadap dunia. Dengan kata lain, kesalehan individual tidak terlepas dari kesalehan sosial dan kesalehan enviromental. Hal ini tidak mungkin tercapai tanpa ada waktu-waktu tertentu yang digunakan khusus untuk mengamalkan ajaran-ajaran tasawuf ini, seperti apa yang disinyalkan Ibn Bajjah dengan filsafat manusia menyendirinya yang ia tuangkan dalam buku utamanya Kitâb Tadbîr al-Mutawahid.

Perlu diinformasikan bahwa pada era global kehadiran tasawuf mutlak diperlukan. Gerakan neo sufisme pada masa pasca modern dalam rangka merespon kepesatan ilmu modern yang cenderung membawa krisis kemanusiaan dapat dijadikan indikasi ke arah ini.

Dengan ajaran tasawuf manusia dapat terbebas dari penyakit manusia modern, seperti kemunafikan, kehampaan rohani dan lain-lainnya, sehingga terciptalah manusia yang utuh. Rasanya sulit dipercaya, sebuah peradaban yang 
menegasikan Allah akan dapat melahirkan kedamaian dan ketentraman sebagai dambaan setiap manusia. Kedamaian ini bisa tercipta dari pribadi yang sehat, yang memiliki akhlak yang mulia. Memang faktualnya dunia ini sangat membutuhkan tasawuf, karena dalam tasawuf tidak hanya terlahir kedamaian, tetapi juga masa depan manusia dan alam semesta. Tentu saja tasawuf yang kita inginkan ialah tasawuf seperti yang diamalkan umat Islam era klasik, yang dengannya mereka mampu menandingi kemajuan umat-umat lainnya.

\section{Kesimpulan}

Tasawuf Islam suatu ajaran kerohanian (spiritual) yang bersumber dari ruh syariat Islam itu sendiri, yaitu al-Qur'an dan al-Sunnah. Tujuan akhir dari ajaran tasawuf adalah untuk mendekatkan diri kepada Allah sebagai Khaliknya melalui riyadhah melewati stasiun-stasiun atau maqamat-maqamat tertentu, dengan selalu mensucikan jiwa (nafs) lahir dan bathin dalam upaya mempersiapkan diri menggapai márifatullah sampai pada tingkat bertemu dan menyatu dengan Allah menuju kehidpan yang abadi.

Tasawuf Islam tidak menafikan sains, bahkan tasawuf Islam banyak menyumbangkan pemikiran dalam bidang filsafat, sastra, musik, tarian, psikologi, dan sains modern. Masalah keterasingan adalah masalah kejiwaan. Manusia berperan sebagai penyebab munculnya keterasingan dan sekaligus sebagai korban yang harus menanggung akibatnya. Dalam konteks ajaran Islam, untuk mengatasi keterasingan jiwa manusia dan membebaskan dari derita keterasingan, justru harus menjadikan Tuhan sebagai tujuan akhir, Tuhan yang Maha wujud dan Maha absolut. Segala eksistensi yang relatif dan nisbi tidak berarti dihadapan eksistensi yang Maha absolut.

\section{Daftar Pustaka}

Al-Qusyayri, (1990), Risalah Sufi, Bandung: Pustaka Setia.

Al-Kalabadzi, (1969), Al-Ta’aruf li Mazhabi Ahli al-Tasawwuf, Kairo: Maktabah al-Kulliyah al-Azhar.

Abd A’la, (2992), Melampaui Dialog Agama, Jakarta: Kompas.

Ali, Yunasril, (1997), Manusia Citra Ilahi Pengembangan konsep Insan Kamil Ibn Arabi oleh al-jili, Jakarta: Paramadina.

Azra, Azyumardi, (2002), Histografi Islam Kontemporer, Jakarta: PT. Gramedia Pustaka Utama, 2002.

Burchard's, Titus, (1973), An Intruduction to Sufi Doctrine, Lahore: SH Muhammad Ashraf. 
Dahri, Harapandi, (2007), Meluruskan Pemikiran Tasawuf Upaya Mengembalikan Tasawuf Berdasarkan Al-Qur'an dan Al-Sunnah, Jakarta: Pustaka Irfani, 2007.

Jamil, (2007), Cakrawala Tasauf Sejarah Pemikiran dan Kontekstualitas, Jakrta: Gaung Persada Press.

Kahmad, Dadang, (2002), Tarekat dalam Islam Spritual Masyarakat Modern, Bandung: CV. Pustaka Setia.

Kartanegara, Mulyadhi, (2006), Menyelami Lubuk Tasauf, Jakarta: Erlangga.

Muhammad, Hasyim, (2002), Dialog Antara Tasawuf dan Psikologi, Yogyakarta: Pustaka Pelajar, 2002.

Nasr, Sayyed Hossein, (1976), Man and Nature: The Spritual of Crisis Man, (London: A Mandala Book-George Allen \& Unwin Ltd.

Nasution, Harun, (1973), Falsafat dan Misticisme dalam Islam, Jakarta: Bulan Bintang.

(t.t), Kedudukan Tasawuf Dalam Islam, Kumpulan Makalah Paramadina, Jakarta.

Nicholson, Reynold A, (1975), The Mistics of Islam, (London: Routledge and Kegan Paul.

Umari, Barmawi, (1991), Sistimatika Tasawuf, Solo: Ramadhani.

Valiudin, Mir, (2002), Tasauf dalam Quran, Jakarta: Pustaka Firdaus.

Wilcox, Lynn, (1995), Ilmu Jiwa berjumpa Tasawuf, Jakarta: PT. Sumber Ilmu Semesta.

Zar, Sirajuddin, (1997), Logika Berpikir Dalam Islam, Makalah, Seminar IKIP Padang, 31 Juli 1997 